\title{
EMISSION OF HARMFUL SUBSTANCES DURING COMBUSTION OF HEAVY LIQUID FUELS
}

During the combustion of heavy liquid fuels in power boilers - both during firing up boilers and under their low loading - considerable quantities of carbon monoxide, nitrogen oxides, polycyclic aromatic hydrocarbons (PAHs) and soot are produced. The PAHs condense on the soot in amounts often exceeding $50 \%$ of their total concentration in the flue gas. The quantity of harmful substances emitted during the combustion of liquid fuels is determined by the organization of the combustion process and in particular by the design of the burners and that of the combustion chamber. In this paper, the results of pollutants' emission tests for an internal-mixing steam-oil burner characterized by low emission of toxic substances and stable operation in a wide range of loading are reported.

\section{INTRODUCTION}

In Polish power plants, liquid fuels are chiefly used for firing up boilers and then to stabilize the operation of the main powdered-fuel burners under reduced boiler loading. Mazout and fuel oils are commonly used for these purposes.

Droplets of atomized oil are introduced into the combustion chamber by an oil burner and as they evaporate they form an air-fuel mixture. At a high temperature the latter ignites forming a flame front. The space between the flame front and the burner nozzle outlet cross-section should have such a geometric form and aerodynamic conditions that the temperature inside it is lower than the cracking temperature of the liquid-phase (unevaporated droplets) and gaseous-phase fuel. If cracking begins in the liquid phase, carbon from the fuel precipitates as coke, and if it starts in the gaseous phase, soot forms. The larger the number and size of soot particles emitted from the flame, the poorer the atomization, the higher the initial viscosity, the higher the $\mathrm{C} / \mathrm{H}$ ratio, the more aromatic compounds in the fuel and the larger the stream of the fuel combusted.

*Institute of Thermal Engineering and Fluid Mechanics, Wroclaw University of Technology, Wybrzeże Wyspiańskiego 27, 50-370 Wrocław, Poland.

"Cracow Heat and Power Station, Cracow, Poland. 
Besides soot other hydrocarbon constituents are formed - chiefly polycyclic aromatic hydrocarbons (PAHs) [1]-[4]. Over 150 different hydrocarbons have already been identified in the flue gas produced during the combustion of liquid fuels [5]. The hydrocarbons are formed as a result of incomplete and unburned combustion.

Incomplete (partial) oxidation can result from an interruption of fuel oxidation due to the "quenching" effect of the surrounding environment, e.g. cold air streams, cold boiler walls or lack of oxygen.

Unburned combustion results from the separation of large drops from the flame into the surrounding environment. In such a case we say that the burner is "leaking". Hard to remove deposits form on the heatable surfaces. The quality of spraying, whose measures are as follows: the size of droplets, their distribution and concentration in the gas stream, is an important combustion parameter since it largely determines the rate of evaporation and air-fuel mixture formation. Fuel droplets should be as small as possible and of similar size and their distribution and concentration in the stream should be possibly uniform. If both these conditions are not fulfilled, they coalesce and larger drops reach the flame front zone before evaporation ends, which leads to unburned combustion.

\section{FORMATION OF HARMFUL FLUE-GAS COMPONENTS DURING COMBUSTION OF LIQUID FUELS}

Many compounds produced during the combustion of liquid fuels contribute to the pollution of the environment, but only some of them, e.g., nitrogen oxides, carbon monoxide, hydrocarbons (including polycyclic aromatic hydrocarbons) and soot, can be controlled by the design of the burner.

\subsection{SOOT FORMATION}

Significant advances in the understanding of the mechanism of soot formation during the oxidation of hydrocarbons have been made in the last 50 years. This does not mean, however, that this problem has been solved. Still we do not fully know how hydrocarbon molecules, which contain only a few carbon atoms and a considerable number of other elements, are converted into carbon molecules containing millions of carbon atoms [6]-[8]. The formation of soot molecules is mainly linked with pyrolysis and oxidizing pyrolysis occurring during combustion in oxidizer-deficient regions. Soot can form both in the gaseous phase and in heterogeneous systems. HUCKNAL [1] claims that fuels, which contain aromatic hydrocarbons, form soot more readily than other hydrocarbons do. According to SŁUPEK [2], soot may also form in the postflame zone at a temperature below $1273 \mathrm{~K}$ in the following low-temperature reaction:

$$
2 \mathrm{CO} \leftarrow \rightarrow \mathrm{CO}_{2}+\mathrm{C}_{\mathrm{s}} .
$$


The number and size of soot particles in the flame increase with the $\mathrm{C} / \mathrm{H}$ and $\mathrm{C} / \mathrm{O}$ ratios and they depend on:

- the boiling points of the particular hydrocarbon compounds in the fuel,

- the initial size of droplets,

- the initial viscosity and the rate of flow of the fuel combusted,

- the rate at which temperature rises in front of the flame zone,

- the concentration of oxygen in the combustible mixture,

- the structure of the flame front.

From the thermodynamic point of view, carbon will be oxidized in the flame if the $\mathrm{C} / \mathrm{O}$ ratio is higher than one. The experimentally determined limit of soot formation is close to 0.5 , and not to 1 [9]-[12]. At an oxygen deficiency the formation of soot can be partially suppressed by steam [13]. During pyrolysis fuel droplets can turn directly into soot. Soot particles are a major source of particles the diameter of which is below $10 \mu \mathrm{m}$ and which are regarded to be extremely hazardous.

\subsection{FORMATION OF CARBON MONOXIDE}

Carbon monoxide is formed mainly in the post-flame zone. The principal cause of the presence of $\mathrm{CO}$ in the flue gas is oxygen deficiency. The kinetics of $\mathrm{CO}$ formation is highly complex and it cannot be represented by simple reactions. So far it has been determined for some low hydrocarbons only. Carbon monoxide can be formed in the high-temperature oxidation of hydrocarbons (e.g. $\mathrm{CH}_{4}$ ) and in low-temperature oxidation in the so-called cold flame - in the case of methane this takes place at a temperature below $823 \mathrm{~K}$ [14]. Carbon monoxide can also be a product of dissociation of $\mathrm{CO}_{2}$ at high temperatures of the post-flame zone.

\subsection{FORMATION OF POLYCYCLIC AROMATIC HYDROCARBONS (PAHS)}

The formation of soot is inextricably linked with the formation of PAHs. Even relatively small amounts of PAHs are regarded to be mutagenic and carcinogenic. The mechanisms of PAH and soot formation in the flame have not been understood sufficiently well. This is due to the complexity of the phenomena occurring at high temperatures in a very short time with several hundred stable and unstable particles and radicals participating and at the same time being subject to oxidation, pyrolysis, isomerization and polymerization [15]-[18].

Polycyclic aromatic hydrocarbons (PAHs) emitted in the flue gas from the combustion of liquid fuels are formed in high-temperature pyrolysis of hydrocarbons. PAHs formed in high-temperature decomposition of fuel in a reducing atmosphere contain mainly carbon and hydrogen. The low-temperature decomposition of hydrocarbons proceeding in a slightly reducing atmosphere creates conditions for the formation of PAHs containing oxygen and sulfur atoms besides carbon and hydrogen atoms. 
The flame tendency to generate PAHs is determined by many factors. It has become known now that the fuel chemical properties determine PAH formation [15]. The other factors contributing to an increase in the concentrations of PAHs and soot in the flame are as follows: temperature, oxygen concentration and in the case of a liquid fuel also atomization, dispersion, evaporation and mixing. All these factors, except the fuel chemical properties and temperature, can be conducive to the formation of oxidizer-deficient zones and as a result orient the fuel oxidation mechanism towards pyrolytic reactions.

PAHs after passing through the combustion zone undergo condensation on soot or other solid particles.

\subsection{FORMATION OF NITROGEN OXIDES}

Three mechanisms of nitrogen oxide formation in combustion processes are distinguished:

- thermal $\mathrm{NO}_{x}$ formation as a result of the oxidation of atmospheric nitrogen,

- prompt nitrogen oxide formation,

- fuel $\mathrm{NO}_{x}$ formation as a result of the oxidation of organic nitrogen bound in the fuel.

The fuel nitrogen oxide comes from the nitrogen organically bound with the fuel. The amount of nitrogen in liquid fuels is so small that it has no significant effect on $\mathrm{NO}_{x}$ emission.

The prime source of nitrogen oxide emission from the oil flame is atmospheric nitrogen oxidized in the post-flame zone. At a high temperature thermal nitrogen oxide is formed according to the extended Zeldowicz mechanism, being commonly known and accepted. The rate, at which nitrogen oxide is formed, depends strongly on temperature and much less on oxygen concentration and it is described by the following equation [19]:

$$
\frac{d[\mathrm{NO}]}{d t}=1.45 \times 10^{17} T^{-1 / 2} \exp \left[-\frac{69460}{T}\left[\mathrm{O}_{2}\right]_{\mathrm{eq}}^{1 / 2}\left[\mathrm{~N}_{2}\right]_{\mathrm{eq}}\right] \quad\left[\mathrm{mol} /\left(\mathrm{cm}^{3} \cdot \mathrm{s}\right)\right] \text {. }
$$

The NO concentrations measured in the flame are usually higher (from a few to $100 \mathrm{ppm}_{\mathrm{v}}$ ) than the ones calculated according to the Zeldowicz mechanism accepted for equilibrium concentrations of the reagents. This excess nitrogen oxide is called prompt NO. Three mechanisms of prompt NO formation are commonly assumed:

- the occurrence of the above-equilibrium concentrations of $\mathrm{O}$ and $\mathrm{OH}$ radicals in the reaction zone and in the post-flame zone generates higher NO concentrations - this mode of prompt NO formation is characteristic of diffusive flames and kinetic low-pressure flames,

- reactions of hydrocarbon radicals with atmospheric nitrogen gives cyanic compounds which when oxidized produce $\mathrm{NO}$ - this is characteristic of kinetic hydrocarbon flames rich in fuel and diffusive flames, 
- the formation of $\mathrm{N}_{2} \mathrm{O}$ and, consequently, $\mathrm{NO}$ - this is characteristic of fuel-poor flames and low-temperature processes.

The first two mechanisms are characteristic also of liquid fuels.

As is commonly known, the concentration of $\mathrm{NO}_{2}$ in the flame is low. Because of the high concentration of $\mathrm{HO}_{2}$ at low temperature and the high concentrations of $\mathrm{H}$, $\mathrm{OH}$ and $\mathrm{O}$ radicals, $\mathrm{NO}_{2}$ converts into $\mathrm{NO}$. Methods of reducing the $\mathrm{NO}$ concentration in combustion products consist in the lowering of temperature in reburning, air staging and flue gas recirculation applied.

\section{TEST PROGRAMME AND METHODS}

The combustion of heavy liquid fuels in steam boilers, particularly in such an extreme situation as the firing up a cold boiler, proceeds with an efficiency below $80 \%$. Therefore such a way of conditioning the fuel for spraying and combustion is sought that will ensure stable and fast firing in extreme conditions, i.e. in a cold combustion chamber. It is desirable that the burner should ensure perfect and complete combustion and should not pose any technical and operational difficulties when the size of burner device is increased (a module changed). It is also necessary to eliminate or neutralize the factors responsible for the formation of soot and carbonized coal in the post-flame zone.

The nozzle of a new type of low-pressure, internal-mixing steam-oil burner with a wide control range from 15 to $130 \%$ of the rated output is shown in figure 1 .

Fig. 1. Diagram of nozzle assembly of low-pressure, internal-mixing oil burner: 1 - steam, 2 - oil

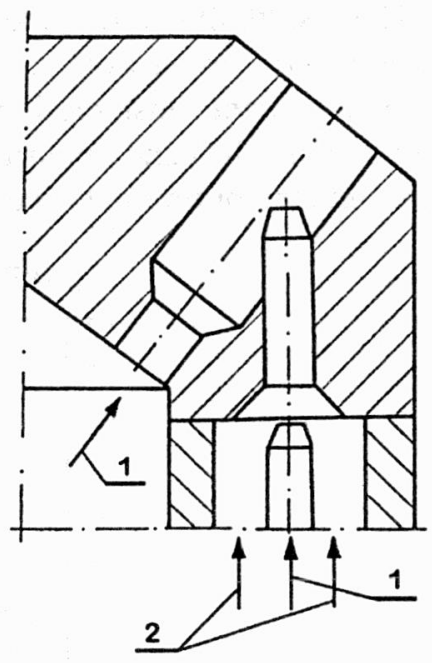

This nozzle design enables the combustion of any liquid fuels: from diesel oils to heavy fuels such as mazouts and asphalts. The fuel pressure can be changed freely in a range of $0.02-1 \mathrm{MPa}$. Either steam or air at a pressure of $0.2-1.2 \mathrm{MPa}$ can be the spraying agent. This burner design is protected by patents [13], [20]-[23]. 
The combustion process was investigated and the characteristics of the burners were determined on a test stand in Energoinvest ITEN Sarajevo and on an OP-650k boiler (during its cold banking) of the $200 \mathrm{MW}$ power unit in Jaworzno III Power Plant on the basis of the scheme presented in [24]. Tests were carried out on burners with the following rated mazout output: $B=0.6,0.8,1.0,2.0,3.0,4.0,5.0 \mathrm{~m}^{3} / \mathrm{h}$.

The combustion process was assessed for the following operating parameters of a burner:

- mazout pressure of $0.015-1.2 \mathrm{MPa}$,

- mazout temperature of 343-413 K,

- spraying steam pressure of $0.15-1.5 \mathrm{MPa}$,

- steam temperature of 423-523 K,

- spraying air pressure of $0.15-0.6 \mathrm{MPa}$,

- air temperature of $293-473 \mathrm{~K}$.

Flow rates of working medium and parameters for mazout, steam and air as well as the flame temperature, the flue gas composition (CO, $\mathrm{CO}_{2}, \mathrm{NO}_{x}, \Sigma \mathrm{C}_{n} \mathrm{H}_{m}$, PAHs) and the soot number were measured. The flue gas composition was determined by means of an ULTRAMAT23 analyzer of the NDIR type, an IMR-3 analyzer and a gas chromatograph coupled with a mass spectrometer.

\section{RESULTS}

The results illustrating the influence of mazout pressure and steam pressure on the ignition and combustion of mazout are shown in figure 2 . The regions bound by curves represent: unstable ignition and pulsating burning - below curve 1, complete combustion -1-3 and unburned and incomplete combustion - above curve 3 . Curve 2 represents the optimum burner operating range.

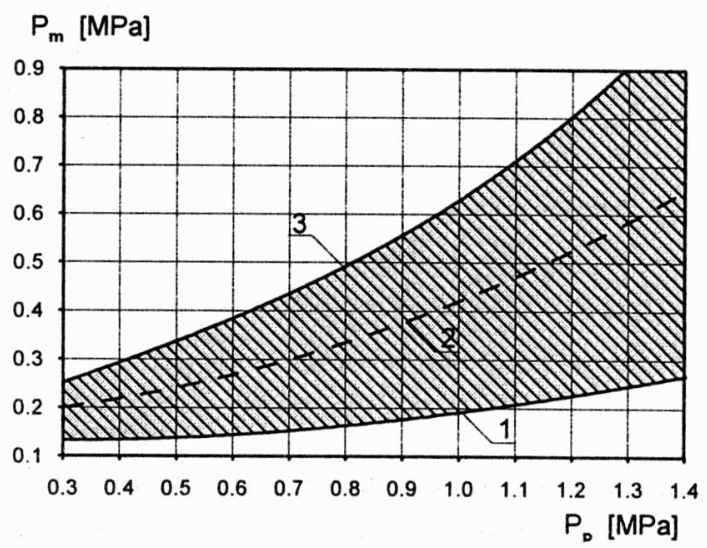

Fig. 2. Influence of mazout pressure $\left(P_{m}\right)$ and steam pressure $\left(P_{p}\right)$ on combustion: 1-2 unstable ignition, pulsating burning, 2-3 complete combustion, 3 - unburned and incomplete combustion 
In the unstable ignition and pulsating burning region, the flame front does not stabilize itself in one position relative to the nozzle outlet, but oscillates continuously. In this region, fuel ignition is unstable and it tends towards increasingly higher fuel pressures - with increasing the atomizing agent pressures. From above the burner unstable operation region is bound by a limit mazout pressure curve (curve 1). The lower twophase mixture ignition limit below which the mixture is too poor for ignition to occur is situated $20 \%$ below curve 1 .

In the upper part of the diagram, the light yellow colour of the flame gradually changes into dark yellow, orange and dark red as the mazout pressure increases. Soot appears in a pulsatory manner in the middle part of the flame. The flame is smoking and drops of unburned fuel get into its surroundings.

\subsection{SOOT}

The soot concentration was described by the Baharah soot number $\left(L_{s} B\right)$. In the complete combustion regions (curves 1 and 2, figure 3), where the flame colour is blue-lightyellow, soot practically does not occur. The soot number in the pulsating burning region is practically equal to zero, and in the region of burner optimum operation it increases slightly along the flame and it is below 0.5 in the end part of the flame.

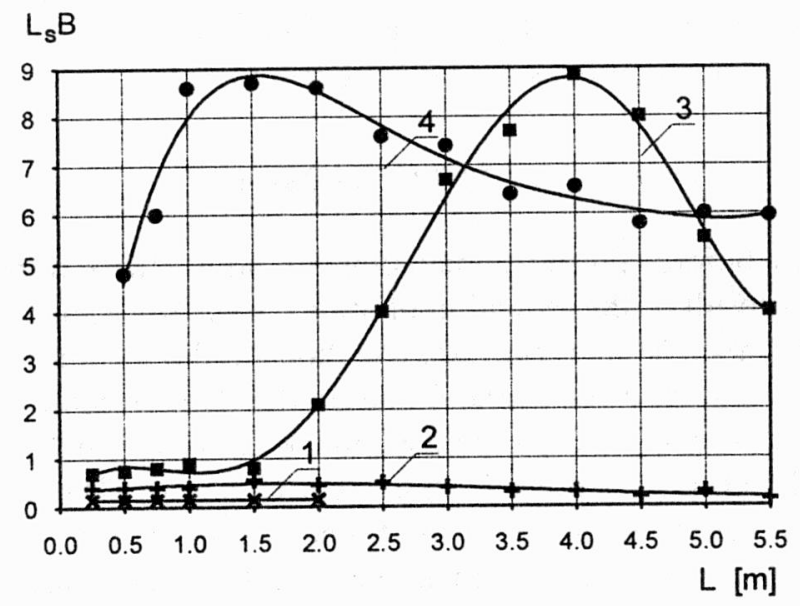

Fig. 3. Relationship between the Baharah soot number $\left(L_{s} B\right)$ and the distance from nozzle outlet cross-section and burner operating region for: 1 - unstable ignition, pulsating burning;

2 - complete combustion; 3 - unburned and incomplete combustion, smoking flame and droplets breaking away from flame; 4 - pressure burner's flame

For unburned and incomplete combustion, at which the flame's colour changes from dark yellow into red, plates of "smoke" appear, the soot number at the beginning 
of the flame increases slowly and then rapidly, reaching maximum values at $1 / 3$ of the flame's length (curve 3).

For comparison, figure 3 shows curve 4 representing the soot number along the flame of a Babcock pressure burner operating at a pressure ( $3 \mathrm{MPa}$ ) close to the rated one. For this burner the soot number reaches a maximum already in the first part of the flame. A comparison of the optimum operating range of the pressure burner (curve 4) and that of the steam-oil burner (curve 2) shows that the soot number is several times higher for the Babcock burner.

\subsection{CARBON MONOXIDE}

The flame front width in the initial zone is about $0.1 \mathrm{~m}$ and about $0.2 \mathrm{~m}$ in the final zone. The maximum CO concentration occurs in the flame's front and it increases along the flame's axis. In the post-flame zone, the concentration of $\mathrm{CO}$ falls to zero. The increase in the $\mathrm{CO}$ concentration along the flame's axis is caused by the progressing thermal decomposition of hydrocarbons. In the initial zone of the flame, the concentration of $\mathrm{CO}$ along the axis is negligible - practically equal to zero.

The concentration of $\mathrm{CO}_{2}$ increases along the flame's axis and it reaches the highest values at the end of the flame.

The oxygen concentration is closely associated with the concentrations of $\mathrm{CO}$ and $\mathrm{CO}_{2}$ in the flame front zone and in the post-flame zone. The oxygen concentration decreases rapidly and it stabilizes in the flame front zone.

\subsection{NITROGEN OXIDES}

As mentioned before, during combustion of liquid fuels nitrogen oxides $\left(\mathrm{NO}_{x}\right)$ form, mainly as a result of the oxidation of atmospheric nitrogen.

The distribution of $\mathrm{NO}_{x}$ in the cross-section of the steam-oil burner's flame is similar to the distribution of $\mathrm{O}_{2}$ in the flame. In the flame's central part, where the $\mathrm{O}_{2}$ concentration is low, the excess oxidizer number is lower than or at the very most equal to one and $\mathrm{NO}_{x}$ practically does not occur (figure 4). The maximum concentration of $\mathrm{NO}_{x}$ occurs at the interface of the flame's front and the post-flame gas where the excess oxidizer number values are above one. Also maximum temperature occurs in this zone. This distribution of flame nitrogen oxide concentration is characteristic of the internal-mixing steam-oil burner.

A quite different distribution of nitrogen oxide concentrations occurs when mazout is combusted in pressure burners. This is connected with the structure of the flame and its aerodynamics. There is no clearly defined flame front here and combustion proceeds in the whole flame volume at oxygen concentrations above one, in a longer reaction time and at similar flame temperature. Hence the $\mathrm{NO}_{x}$ concentration increases (curve 2 in figure 4 ) along the whole length of the flame and only at the flame's end decreases slightly. 


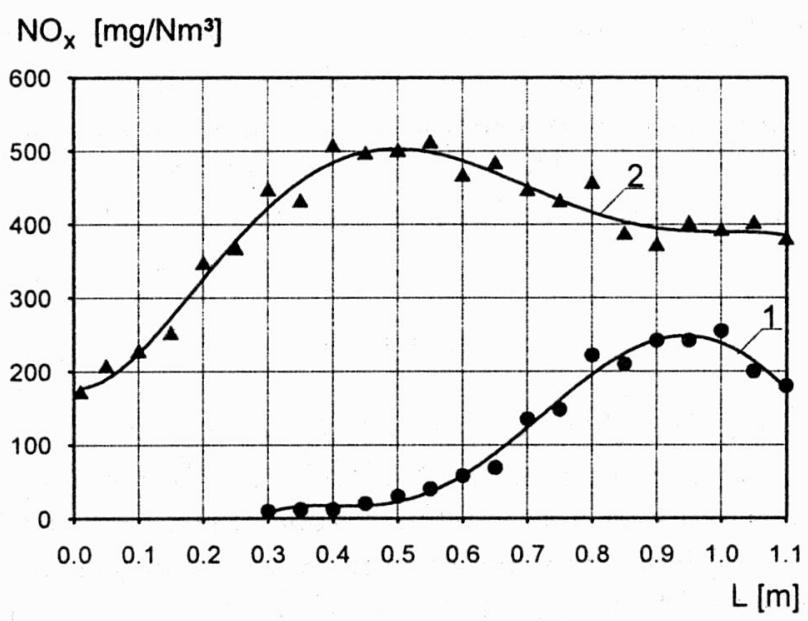

Fig. 4. $\mathrm{NO}_{x}$ concentration along flame: 1 - internal-mixing steam-oil burner; 2 - the Babcock pressure burner

In the case of the pressure burner, the concentration of $\mathrm{NO}_{x}$ is much higher than that of $\mathrm{NO}_{x}$ formed during the combustion of mazout in the steam-oil burner (curve 1).

\subsection{POLYCYCLIC AROMATIC HYDROCARBONS}

The distribution of PAH concentration along the axis of the flame of mazout combusted in the Babcock pressure burner (curve 1) and in the internal-mixing steam-oil burner (curve 2) is shown in figure 5 . The concentration of PAHs in the flame of the pressure burner is several times higher than that characteristic of the steam-oil burner.

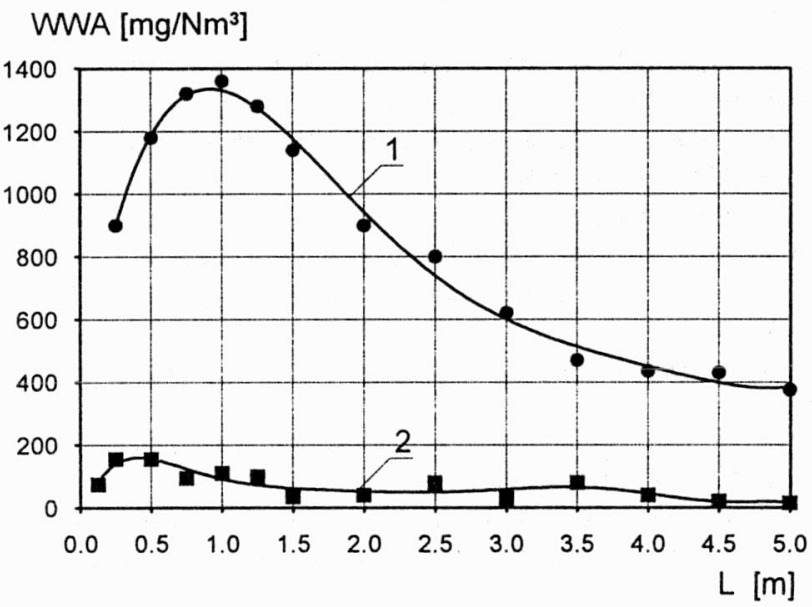

Fig. 5. Concentration of PAHs along flame:

1 - pressure burner, 2 - internal-mixing steam-oil burner 
The maximum PAH concentration occurs in the initial zone of the flame near the flame front, being more distant in the case of the pressure burner. This is probably caused by the more intensive combustion in the initial zone of the flame where hightemperature oxidation occurs. The rate of growth of PAHs is slowed down by their oxidation and rapid decomposition in the oxygen-rich zone of the flame.

\section{CONCLUSIONS}

The combustion of liquid fuels - particularly heavy fuels - in boiler firing up conditions is characterized by high emission of $\mathrm{CO}$, soot, $\mathrm{NO}_{x}$ and PAHs. In order to reduce $\mathrm{NO}_{x}$ emission, oxidizer-poor reduction zones must be formed in the flame and the temperature of the latter must be lowered. But such proceedings contribute to the formation of PAHs and CO. The emissions of all these constituents can be reduced simultaneously by introducing new burner designs with optimized fuel atomization, evaporation and mixing with air. An example of such a design is the internal-mixing steam-oil burner presented.

\section{REFERENCES}

[1] Hucknal D.J., Chemistry of Hydrocarbon Combustion, Chapman and Hall, London, New York, 1985.

[2] SŁUPEK S., Proces spalania wodnych emulsji paliwa ciektego, ZN AGH, Mat. Odl., z. 75, 1977.

[3] Warnatz J., Maas U., Dibble R.W., Combustion. Physical and Chemical Fundamentals, Modeling and Simulation, Experiments, Pollutant Formation, Springer-Verlag, Berlin-Heidelberg, 1999.

[4] SŁUPEK S., O możliwości ograniczenia szkodliwości produktów spalania paliw ciekłych, Hutnik, 1984, nr 11, 404.

[5] KowalewICZ A., Tworzenie mieszanki i spalanie w silnikach o zaptonie iskrowym, WKiL, Warszawa, 1984.

[6] Kronenburg A., Bilger R.W., Kent J.H., Modeling soot formation in methane-air mixtures, Combustion and Flame, 2000, Vol. 121, pp. 24-40.

[7] KRESTININ A. V., Detailed modeling of soot formation in hydrocarbon pyrolysis, Combustion and Flame, 2000, Vol. 121, pp. 513-524.

[8] Wang R., Cadman O., Soot and PAH production from spray combustion hydrocarbons behind reflected shock waves, Combustion and Flame, 1998, Vol. 112, pp. 359-370.

[9] LAW C.K., Recent advances in droplet vaporization and combustion, Prog. in Energy and Combust. Science, 1982, Vol. 8.

[10] FAETH G.M., Current status of droplet and liquid combustion, Prog. in Energy and Combust. Science, 1977, Vol. 3.

[11] WILK R., Badania zjawiska spalania kropli ciężkiego paliwa ciekłego, Zeszyty Naukowe Pol. Śląskiej, Energetyka, 1982, nr 81, Gliwice.

[12] Kulagin L.V., OChotnikov S.S., Sziganie tjażelych żidkich topliv, Nedra, Moskwa, 1967.

[13] KarCZ H., WosiK W., Jodkowski W., Palnik do spalania paliwa ciektego, Patent $\mathrm{nr} 166575 \mathrm{z}$ dnia 13.03.1992.

[14] Glassman J., Combustion, Academic Press, New York, San Francisco, London, 1977.

[15] Vincitore A.M., SEnKan S.M., Polycyclic aromatic hydrocarbon formation in opposed flow diffusion flames of ethane, Combustion and Flame, 1998, Vol. 114, pp. 259-266. 
[16] LEUNG K.M., LindSTEDT R.P., Detailed kinetic modeling of $C_{1}-C_{3}$ alkane diffusion flames, Combustion and Flame, 1995, Vol. 102, pp. 129-160.

[17] TYLER R.M., FIKRET I., SELIM M.S., The effects of equivalence ratio on the formation of polycyclic aromatic hydrocarbons and soot in premixed ethane flames, Combustion and Flame, 1998, Vol. 114 , pp. 192-213.

[18] Wang H., Frenklach M., A detailed kinetic modeling study of aromatics formation in laminar premixed acetylene and ethylene flames, Combustion and Flame, 1997, Vol. 110, pp. 173-221.

[19] KozIŃSKı J.A., PAH formation and interaction in semipractical flames of liquid fuels, Combustion and Flame, 1994,Vol. 96, pp. 249-260.

[20] Wanatowicz S., KarCZ H., Palnik olejowy. Świadectwo Autorskie Wzoru Użytkowego Ru 43115 $\mathrm{z}$ dnia 30.10.1985.

[21] Wanatowicz S., Karcz H., Zembrzuski M., Palnik do spalania paliwa ciekłego. Patent nr 150725 $\mathrm{z}$ dnia 30.01.1987.

[22] Karcz H., Palnik energetyczny paliwa ciekłego. Wzór Użytkowy nr W 108991 z dnia 23.09.1994.

[23] Karcz H. et al., Palnik do spalania paliwa ciekłego. Patent nr 164172 z dnia 1.10.1990.

[24] Karcz H., Wosik W., Modlinski Z., Butmankiewicz J., Sędzielowski E., Matlak W., Gazodynamiczny palnik olejowy $z$ wewnętrznym mieszaniem, Zeszyty Naukowe Politechniki Śląskiej, Seria: Energetyka, 1994, z. 121, pp. 12-27.

\section{EMISJA SZKODLIWYCH SUBSTANCJI PODCZAS SPALANIA CIĘŻKICH PALIW PŁYNNYCH}

W procesie spalania ciężkich paliw płynnych w kotłach energetycznych zarówno w fazie rozruchu, jak i przy niskich obciążeniach kotła powstają znaczne ilości tlenku węgla, tlenków azotu, wielopierścieniowych węglowodorów aromatycznych (WWA) oraz sadzy. Na sadzy kondensuje WWA w ilościach niejednokrotnie przekraczających $50 \%$ ich sumarycznego stężenia w spalinach. Ilość emitowanych substancji szkodliwych pochodzących ze spalania paliw płynnych zależy od organizacji procesu spalania, a w szczególności od przyjętych rozwiązań konstrukcyjnych palników i komór spalania.

W artykule przedstawiono wyniki badań, które dotyczą emisji zanieczyszczeń z palnika gazodynamicznego $z$ wewnętrznym mieszaniem. Palnik taki charakteryzuje się niską emisją substancji toksycznych, a jednocześnie jego praca jest stabilna w bardzo szerokim zakresie obciążeń. 
